\title{
The Origin and Development of Chinese Nationalism and Its Practical Implications
}

\author{
Xiangbo Zhu* \\ School of Marxism, Northwestern Polytechnical University, Xi'an, 710072, P. R. China \\ School of Marxism, Henan Mechanical and Electrical Vocational College, ZhengZhou, 410000, P.R. China \\ ${ }^{*}$ Corresponding author. Email: q155492328@163.com
}

\begin{abstract}
The various nationalist trends in contemporary China have played an important role in political movements and local conflicts around the world, but the reasons for their origins and trends vary widely. Contemporary Chinese nationalism, however, is often expressed in terms of 'patriotism' because of its stressful character. By tracing the origins of Chinese nationalism and sorting out the development skeleton of Chinese nationalism, analyzing the current situation and its profound historical background, with the aim of providing basic theoretical support for the construction of contemporary nationalism theories.
\end{abstract}

Keywords: Nationalism, Origin and development, Influence on reality.

\section{INTRODUCTION}

Nationalism, i.e. an idea or movement based on the interests of the national interests, was born in the West and as the source of modern international society promoted national liberation and equality. It is a social trend that has influenced the political ecology of the world. Many patriots have used nationalism as an ideological weapon to explore the way to save the country and make the country prosperous after it was introduced to China in the late 19th and early 20th centuries, thus becoming an important ideological power that has influenced Chinese politics.

Since the 1990s, various nationalist trends have played an extremely important role in political movements and local conflicts around the world. It is predicted that nationalism will be the most important political trend of the twenty-first century. In the postCold War period when the East-West Cold War ended and the trend of world multi-polarization developed, a torrent of nationalism originating in Eurasia is once again spreading rapidly around the world, forming the third wave of nationalism in the twentieth century. The struggles and frictions marked by nationalism can be felt in almost every corner of the planet. Nationalism shows no sign of dying out in globalization. Instead, it has witnessed the most widespread and powerful development since the Second World War. Contemporary nationalism not only affects the internal development of countries and nations over the world but also hampers the global peace and development. The extent of its influence is deeper than one might expect, and it has become a focus of real concern and a hot topic of academic research today.

\section{DEFINITION OF CHINESE NATIONALISM, TRACING IT FROM ETYMOLOGY}

Nationalism is a less systematic theoretical form as a political trend. It is a widely debated issue, both in China and abroad, among the folk and in the theoretical community. For example, Ernest Gellner argues that "nationalism is primarily a political principle which insists that political and national units must coincide" and that "without modern state power, there is no question of nationalism"[1]; John Bourgeois argues that: "nationalism is a political form that refers to a political movement that seeks and holds state power and uses nationalism as a reason to justify this behaviour [2] and so on. In contrast, according to Marx and Lenin, nationalism is a narrow national consciousness, a preference for one's own nation; and although nationalism can be divided into progressive and reactionary, but in essence, nationalism is the core of the bourgeois national view, and as such, as a historical phenomenon, it will gradually disappear with the development and progress of society. [3]. The American 
historian and diplomat Carlton Hayes pointed out that "a complete and systematic study of the attributes and history of patriotism, nationhood and nationalism does not exist in any language." [4]

We can look at the chart of ethnic and national identities in Anthony Smith's Nationalism: Theory, Ideology, and History. (Table1.Characteristics of ethnic groups and peoples)From this point of view, religious beliefs can not be a criterion for defining ethnicity.This is relatively objective. The precise "common mythology", "shared history", "common public culture", etc. , which are the basic conditions for national identity, and thus it is clear that the 56 nationalities of China refer more to ethnic groups, while the Chinese national concept is a more precise definition of the basis of China as an ethnic nation.

Table 1. Characteristics of ethnic groups and peoples [5]

\begin{tabular}{|l|l|}
\hline \multicolumn{1}{|c|}{$\begin{array}{c}\text { Ethnic group } \\
\text { Appropriate name }\end{array}$} & \multicolumn{1}{c|}{$\begin{array}{c}\text { Ethnicity } \\
\text { Appropriate name }\end{array}$} \\
\hline $\begin{array}{l}\text { Common myths and } \\
\text { ancestors, etc. }\end{array}$ & A common myth \\
\hline Shared memories & A shared history \\
\hline A different culture & A common public culture \\
\hline $\begin{array}{l}\text { Connected to the } \\
\text { homeland }\end{array}$ & $\begin{array}{l}\text { Possession of ancestral } \\
\text { lands(homeland) }\end{array}$ \\
\hline $\begin{array}{l}\text { Solidarity of certain } \\
\text { (elites) }\end{array}$ & $\begin{array}{l}\text { Common rights and } \\
\text { obligations }\end{array}$ \\
\hline & Single economy \\
\hline
\end{tabular}

\section{TRACING THE ORIGIN AND DEVELOPMENT OF NATIONALISM IN CHINA FROM A MATERIALISTIC HISTORICAL PERSPECTIVE}

The core of the modern state is the nation state, and in China nationalism began to sprout at least in the Song dynasty, which collided violently with various minority regimes and produced fantastic reactions. Ouyang Xiu, for example, wrote The Theory of Orthodoxy, and while pro-war and anti-war poems were both good in the Tang Dynasty, pro-war poems, such as those of Xin Qiji and Lu You in the Song Dynasty, were politically correct. The idea of Shu Han orthodoxy has already enjoyed the great influence. Rather than being a view of history, it was a search for a realistic identity. The song Dynasty sought the rationality of political power and state, which was a far-source of nationalism in modern China.

\subsection{Perspective of the World}

From a cultural point of view, the main reason for the absence of nationalist thinking and movements in ancient China was the narrow concept of "Tian-Xia Doctrine" and the"distinction between yi and xia", which had long restricted the Chinese people's vision of the world. The idea of "Tian-Xia Doctrine"or the idea of the world was a long-standing pattern of understanding the world in ancient China. According to the oldest Chinese literature, it dates back to ancient times. According to this idea, the "world" i.e. the whole world, was equated with the realm of the orthodox dynasty, and the phrase "Every place under the whole heaven is the king's land. Every man within the four seas is a subject of the king"[6] typifies this idea. This is a typical reflection of this idea. The ruler of the dynasty ruled the world according to the mandate of providence, and was called the "Son of Heaven". Everything under the Sun, that is, everything in the world should be subordinated to the "Son of Heaven" and the ruler chosen and ordered by the "Heaven".

The ancient idea of the world was secondly expressed in the concepts of geography and culture. According to the understanding of orthodox dynastic thought, the "world" could be divided geographically into two parts: the 'Kyushu part' and the 'four seas beyond Kyushu'. In terms of location, it can be divided into "China", that is, "Huaxia" and "the four barbarians", i.e. "Man, Yi, Rong and Di". This brings us to an important proposition in ancient Chinese political doctrine, the "distinction between barbarians and Huaxia". As the name implies, it means to distinguish between "Huaxia" and barbarians. The term "Hua" refers to the Huaxia nationality (Han nationality); the barbarian refers to all non-Han nationality. The main purpose of the distinction between barbarians and $\mathrm{Xia}$ is to identify the superiority and inferiority of cultures, i.e. the Chinese culture (Han culture) is superior and civilized, while the barbarian culture is inferior and barbaric. The distinction between barbarians and Xia constitutes the traditional Chinese 'world view' centred on China.

\subsection{From "the World" to "all Nations", the Enlightenment of Chinese Nationalism}

Later on, it gradually became a 'world view' centred on China or Chinese civilization. This view was that China, as the most civilized country, was the center of the world, while outside China were the barbarians, whose culture was barbaric and inferior. The influence of this idea was so profound that until modern times. When the doors of the ancient empire were forced open by the West, many Chinese people still thought of themselves as the empire of heaven. It was difficult for ancient China to develop a sense of national selfconsciousness and a modern sense of nationhood based on civilizational and racial differences, and it lacked the modern national concepts based on the forest of nations in the world.

The emergence of Chinese nationalism dates back to the modern imperialist invasion. The traditional Chinese 
nationalist ideology was mainly based on a sense of national superiority, the belief that the Chinese nation was at the centre of the world and that civilization was of the highest order. As is well known, China faced deep external and internal strife from 1840 to 1950s, namely the First Opium War and the Taiping Rebellion, which led to the rise of the ideological trend of practical statecraft as the official ideology, replacing the traditional Ching-chu philosophy. The traditional conception of the world finally underwent some kind of change during the foreign affairs movement.

It was only in the 1860 s that Chinese officials and gentlemen began to realize that the world situation in which China found itself had changed dramatically. From the 1860s onwards, the foreign affairs movement, which was characterized by the pursuit of worldly values, was launched. During this period, the principle of practical statecraft was also applied to the rules and methods of foreign relations. We refer to this traditional view of the world that has been transformed by the application of the world, as the China-centred view of world.

\subsection{From "Nations" to "World", the Formation of Chinese Nationalism}

The Sino-Japanese War ended in a crushing defeat for China, which not only could no longer control and dictate Korean affairs, but also signed the powerdefeating Treaty of Shimonoseki with Japan, so that even in East Asia, there could no longer be any extravagant talk of China as the centre. We call this change the de-centring of the all nations' view. The defeat in the First Sino-Japanese War meant the complete collapse of the remaining world order in East Asia, and proved the futility of relying on Confucianism to achieve the goal of enriching the country and gaining a foothold in the world's nation states. The result was that the scholars began to doubt the desirability of Confucian ethics and led to a dramatic change in the concept of Chinese cultural legitimacy, and the modern transformation of traditional Chinese society began to accelerate [7]. It became clear that China was not the only power; China was no longer the 'centre' that Western countries were even more advanced and civilized than China, and that traditional Chinese nationalism was under attack.

In the early twentieth century, intellectuals such as Liang Qichao introduced Western nationalism into China, which, together with traditional Chinese nationalism, formed the basic source of modern Chinese nationalism. Li Hongzhang, an important minister of the late Qing Dynasty, once said that modern China was in the midst of "a great change in more than three thousand years"[8]. Liang Qichao said in 1902, "Therefore, there is no other way to save China today than to build a nationalist state. Who can usurp the emblem of the world's greatest empire if the largest nation on earth can build a country suitable for the evolution of heaven?" [9] Although Liang Qichao still had a glorious dream of a Chinese empire that would be the first in the world, the future China he depicted was no longer a China registered the view of Tian-Xia), but a national state "fit for the evolution of heaven".

From Sun Yat-sen's interpretation of nationalism in terms of "the government of the people, by the people, for the people" to the Communists' Marxist interpretation of nationalism, the development of Chinese nationalism was basically based on the idea of getting rid of the control of other powerful nationalities,with obvious exclusiveness. The May Fourth Movement, which broke out in 1919, was an important milestone in the history of Chinese nationalism. In the 1930s, the Japanese invasion of China led to an unprecedented unity and development of nationalism in the war against Japanese aggression. After the founding of People's Republic of China, Chinese nationalism was closely aligned with a strong Marxist-Leninist ideology.

In summary, Chinese nationalism derives from a number of ideological sources that differ greatly from each other, including: traditional Chinese thinking, American progressivism, Marxism, and Russian populist ideas. This ideology itself also presents many differences, and even often conflicting, manifestations.

\section{CONTEMPORARY CHINESE NATIONALISM AND ITS REALISTIC INFLUENCE}

After 1949, the characteristics of Chinese nationalism have been closely related to the ideological orientation of the Chinese Communist Party. For example, after the establishment of the CCP, it held the Marxist ideology with an internationalist ethos. Under the influence of this internationalist ideology, Chinese nationalism since modern times has become increasingly marginalized and, although it has not completely disappeared, "nationalist aspirations have been directly and forcefully restrained and suppressed by the tenets of ideological philosophy"[10]. However, it was only after the break-up of Sino-Soviet relations and the opening up of China, especially after the dramatic changes in the Soviet Union and the end of the Cold War, that nationalism began to become the focus of people's concern again, through global internationalism.

Firstly, the rise of contemporary nationalism in China is still, to some extent, a stressful social trend.

Modern Chinese nationalism was formed in response to acts of aggression and plunder by the Western powers, and was undoubtedly of a very pronounced stressful nature. In contemporary China, 
although there is no smoke of gunfire, the international pressures caused by the economic rise have been repeatedly appeared. The international "threat theory" and "collapse theory" of China are incessant, and these phenomena, with their exceptionally obvious modern "nationalism", cannot be dispelled in today's world where there are many international coordination organizations. It is undeniable that the law of the jungle, the "Nature selection, and survival of the fittest" predetermined by Western evolutionary theory, is still a reality for contemporary Chinese nationalism, which cannot escape the stressful fate. Under the pervasive "jungle mentality" since modern times, the international situation is changeable is changeable and the motivation of Chinese stress-based nationalism are undoubtedly unsustainable.

Secondly, at a time when ideologies adhering to the tenets of "internationalism" were prevalent, Chinese nationalism was either hidden or embedded in it, and expressed in the concept of 'patriotism'. As Xiao Gongqin puts it, "The ideological symbols of socialism are the expression of Chinese nationalism. Since the concept of nationalism does not enter directly into the ideological symbol system, the connotation of nationalism is characterized by the specific concept of patriotism."[11] In other words, the notion of nationalism was still an undercurrent in China at this time, poised to take hold. In fact, there was a large degree of inherent tension between internationalism and nationalism. For example, the slogan "Chinese Marxism" was raised at the Sixth Plenary Session of the Sixth Central Committee of the Communist Party of China in the 1930s as a tactic of internal political struggle, but we could also feel the intensity of the conflict in the combination of the two. In a sense, internationalism was the means, while nationalism was the essence. This was evident in the liberation movements of the world's colonies in the 20th century. Thus, when the Cold War ended in the early 1990s, people were eager to abandon the internationalist banner they had carried for so many years, and went straightly and unabashedly into the arms of nationalism. This is the reality of contemporary Chinese nationalism.

\section{CONCLUSION}

The nationalism that developed within this modern Chinese value system of the "world" was always only instrumental and phased. As soon as nationalism achieved its mobilizing purpose, or ceased to take social Darwinism as an evolutionary axiom, the moral ideal of world harmony would overshadow nationalism and China could even become the centre of a new world morality once again, which was the New Sinocentrism of the Cultural Revolution, with China as the centre of the world revolution[12]. It was only after the Cultural Revolution that the Chinese realized the falsity of the revolutionary utopia and recognized itself as a member of the nation states in the reform and opening-up after the disintegration of New Sinocentrism.

At the dawn of the 21st century, with China's growing power, it is not surprising that nationalism and narrow nationalism tendency appears in mainland Chinese thinking; but the possibility of integrating the future international order with Chinese world view and culture, as advocated by individual scholars, is worthy of our reflection. Indeed, traditional Chinese civilization and intelligence can certainly provide rich intellectual resources for the future development of mankind, but in tapping these resources, we should also pay due attention to what history has already taught us.

In general, nationalism at the national level in China is still only a pervasive part of the national mood towards foreign threats, and has not yet risen from its native state to become an important spiritual force that can lead the healthy development of society and guide people to view the world rationally, and form a complete set of value systems, social institutions and behavioral norms. Nationalism now remains developing and it is not mature or rational enough. But while it is far from theoretical thinking, it is very close to the people. One cannot understand modern China and look to her future without the involvement of nationalism or without a nationalist perspective. However, among the Chinese classified as nationalists, there are those who advocate authoritarianism and those who advocate the expansion of democracy; those who advocate more government intervention and those who advocate a completely laissez-faire market economy; those who advocate a return to tradition and those who oppose it. Therefore, it is perhaps more realistic and urgent to integrate the existing ideological resources than to explore new nationalist orientations.

\section{REFERENCES}

[1] Ernest Gellner. Ethnicity and Nationalism [M]. Beijing: Central Compilation Press, 2002, pp.1

[2] John Bugeoli. Nationalism and the State [M]. Manchester University Press (English edition), 1985 , pp.3

[3] The complete works of Marx and Engels (Vol. 1) [M]. Beijing: People's Publishing House, 1972, pp.319

[4] Carlton J.Hayes. Essayson Nationalism [M]. New York: The Macmillan Company, 1928, pp.2

[5] Anthony Smith. Nationalism: theory, ideology, history [M]. Shanghai: Shanghai People's Publishing House, 1972, pp.319

[6] Shi Jing - Xiao Ya - Bei Shan Psalm [Z] 
[7] Jin Guantao Liu Qingfeng. A study of the history of ideas:The formation of important political terms in modern China [M]. Beijing: Law Press, 2010, pp.239

[8] Li Hongzhang: "Prepare to discuss the manufacture of ships cannot be abolished, the 15th day of the 5th month of the 11th year of the Tongzhi era", in Li Hongzhang Quanji - Zaozhi V, Anhui Education Publishing House, 2008, pp. 107

[9] Liang Qichao, "On the Great Trend of National Competition" (1902), in The Tenth Collection of the Drinking Ice Room, vol. 4, pp. 35
[10] Xiao Gongqin. The History and Prospects of Chinese Nationalism. Strategy and Management [J]. 1996, No. 2, pp.60

[11] Xiao Gongqin, The History and Prospects of Chinese Nationalism [M], pp.60

[12] Liu Qingfeng, "The New Huaxia Centrism in the Cultural Revolution", Twenty-first Century [J], General No. 15 (February 1993 issue), pp.55-59 